\title{
СЦЕНАРІЙ ЗМІШАНОГО НАВЧАННЯ ЗАРУБІЖНОЇ ЛІТЕРАТУРИ У ПРОЦЕСІ ВИВЧЕННЯ ТЕМИ «ТВОРЧІСТЬ ОНОРЕ ДЕ БАЛЬЗАКА»
}

\author{
Ігор Казаков \\ кандидат філологічних наук, доцент, \\ завідувач кафедри російської мови та літератури \\ ДВНЗ «Донбаський державний педагогічний університет» \\ м. Слов'янськ Донецької області, Україна \\ ORCID ID 0000-0002-7536-6723 \\ kazakov.i@i.ua

\section{Віктор Разживін} \\ кандидат філологічних наук, доцент, \\ доцент кафедри української мови та літератури \\ ДВНЗ «Донбаський державний педагогічний університет» \\ м. Слов'янськ Донецької області, Україна \\ ORCID ID 0000-0002-4512-8791 \\ vrazzhivin@i.ua
}

\begin{abstract}
Анотація. У статті запропоновано сценарій змішаного навчання під час вивчення теми «Творчість Оноре де Бальзака» у курсі історії зарубіжної літератури для вищих навчальних закладів. Подано опис організації різних етапів навчального процесу з використанням модулів системи MOODLE: лекція, навчальне відео, індивідуальні завдання, тест, аудиторна робота тощо. Зазначено актуальність проблеми використання технології змішаного навчання під час викладання у вищому навчальному закладі. Підкреслено, що змішане навчання $\epsilon$ пріоритетною формою вивчення навчальних дисциплін на сучасному етапі.

Ключові слова: змішане навчання; сучасні методи навчання; дистанційні технології; методика викладання; зарубіжна література; Оноре де Бальзак.
\end{abstract}

Постановка проблеми в загальному вигляді. Пандемія 2020 - 2021 років зумовила суттєві зміни у вітчизняній вищій освіті. Поширення коронавірусної хвороби на території України прискорило впровадження в процес навчання інновацій, які передбачають використання різноманітних форм роботи зі студентами, що грунтуються на застосуванні мережевих можливостей. Зрозуміло, що сучасне викладання вимагає готовності до глобальних змін та володіння предметними компетенціями та методиками впровадження інноваційних технологій в навчальний процес. Зокрема, нові умови спонукають до варіативності у випадку відмови від традиційних форм навчання (очна, вечірня, заочна) через розповсюдження COVID - 19. Альтернативою звичному 
вже дистанційному підходу може бути мережева форма чи, наприклад, змішане навчання (англ. blended learning») - гібридна методика, заснована на творчому поєднанні навчання он-лайн і традиційного (аудиторного) навчання. Термін увійшов у загальний обіг після публікації роботи К. Бонка та Ч. Грема «Довідник змішаного навчання» (Bonk, Graham, 2006). Такий тип навчання має значну кількість переваг:

- студент вчиться готуватися до заняття;

- підвищується мотивація студентів;

- робиться акцент на глибокому навчанні;

- ефективне використання часу;

- гнучкість;

- легше контролювати прогрес студентів;

- розширені засоби діагностики;

- інтерактивність;

- викладання в командах (змішане навчання - це командний вид діяльності, який робить процес навчання соціальним і прозорим);

- робота вдома (у деяких випадках викладачі зможуть працювати віддалено);

- розширює навчання за межі однієї «події»;

- дозволяє студентам отримувати навички діяльності;

- економить гроші за рахунок скорочення поїздок;

- краще для досягнення суттєвих результатів;

- більші можливості вчитися;

- різні вимоги навчання (Кухаренко, 2016).

Актуальність запровадження та розвитку змішаного навчання підкреслено у спеціальному листі МОН України (Лист МОН України № 1/9-344, 2020). Разом iз тим для його широкого застосунку необхідне напрацювання великої кількості практичних розробок, адаптованих до різних систем управління навчальною діяльністю.

Аналіз останніх досліджень і публікацій свідчить про досить високий рівень опанування теорією змішаного навчання в Україні. Вдалим прикладом грунтовного підходу до проблеми є колективна монографія «Теорія та практика змішаного навчання» (Кухаренко, 2016). У цій праці комплексно досліджено широкий спектр питань, пов'язаних із змішаним навчанням. Зокрема, подано достатньо міцну теоретичну базу: розглянуто принципи, характеристики й вимоги змішаного навчання, переваги, проблеми та тенденції розвитку. Практична частина спрямована на визначення особливостей змішаного навчання 
у школі. Широке коло публікацій присвячене узагальненню наукових робіт західних вчених та обгрунтуванню необхідності впровадження змішаного навчання в Україні (Бугайчук, 2016; Кузьменко, 2017; Рашевська, 2010; Шуневич, 2009). Практична складова, яка грунтується на розробці конкретних моделей та сценаріїв, представлена менше (Кудін, Міненко, 2018; Чепурних, 2019), що й обумовлює актуальність дослідження.

Метою статті $\epsilon$ розробка сценарію змішаного навчання зарубіжної літератури на прикладі вивчення теми «Творчість Оноре де Бальзака», який надає можливість реалізувати всі елементи засвоєння навчального матеріалу: знання, розуміння, застосування, аналіз, синтез, оцінювання (за таксономією Б. Блума).

Методика дослідження. Пропонований сценарій пройшов апробацію на філологічному факультеті Донбаського державного педагогічного університету (ДДПУ). Процес дистанційного навчання здійснюється у ДДПУ на основі інформаційної системи навчального призначення MOODLE, і пропонований сценарій був інтегрований в середовище платформи MOODLE, що не виключає можливості реалізації описаного нижче сценарію в інших LMS (Learning Management System). У нашому сценарії змішаного навчання використано доволі популярну ротаційну модель «перевернутий клас» (Кухаренко, 2016).

Результати дослідження. Оскільки творчість Бальзака займає чільне місце у літературному процесі XIX століття, пропонуємо присвятити вивченню цієї теми окремий навчальний тиждень, план якого викладач розміщує на своєму е-курсі. План повинен містити інформацію про терміни виконання завдань, форму та місце їхнього проведення й кількість балів, які студент може набрати за кожний вид діяльності. Для оптимізації та прозорості системи накопичення балів кожну тему (модуль) ми оцінюємо у 100 балів, а для переводення набраних балів у семестрову рейтингову оцінку застосовуємо відповідний коефіцієнт.

Пропонуємо план та опис навчальної діяльності за цим сценарієм.

\section{ПЛАН ВИВЧЕННЯ ТЕМИ «МАГІЧНИЙ РЕАЛІЗМ»}

1. Ознайомитися 3 лекційним матеріалом «Творчий шлях Оноре де Бальзака» (дистанційно, термін виконання).

2. Дати відповіді на питання для самоконтролю (дистанційно, термін виконання) - 10 балів.

3. Ознайомитися 3 навчальним відео «Задум та структура «Людської комедії О. де Бальзака»» (дистанційно, термін виконання). 
4. Виконати індивідуальне завдання № 1. «Філософсько-естетичний зміст передмови до «Людської комедії»»» (дистанційно, термін виконання) - 10 балів.

5. Виконати тест за змістом роману Бальзака «Батько Горіо» (дистанційно, термін виконання) - 10 балів.

6. Взяти участь у практичному занятті «Роман Бальзака «Батько Горіо» як «роман кар'єри»» (аудиторна робота, дата, час, місие проведення) - 40 балів.

7. Виконати індивідуальне завдання № 2. «Особливості творчого методу О. де Бальзака» (дистанційно, термін виконання) - 20 балів.

8. Взяти участь у підсумковому вебінарі (дистанційно, дата, час, посилання для входу на вебінарну кімнату) - 5 балів.

9. Виконати рефлексію до занять (дистанційно, термін виконання) - 5 балів.

Максимальна кількість балів за тему - 100 балів.

\section{ОПИС НАВЧАЛЬНОЇ ДІЯЛЬНОСТІ}

\section{1. Лекційний матеріал}

Для викладу лекційного матеріалу в середовищі MOODLE доцільно застосувати вид діяльності «Урок», який надає можливість додати до теоретичного матеріалу питання для самоконтролю.

\section{Оріснтовний план лекції «Творчий шлях Оноре де Бальзака»}

1. Життєвий шлях письменника.

2. Універсальність задуму, тематико-жанровий склад, основні принципи побудови епопеї О. де Бальзака «Людська комедія».

3. Ідейно-художній аналіз творів:

- «Ежені Гранде»,

- «Шагренева шкіра»,

- «Гобсек»,

- «Батько Горіо»,

- «Втрачені ілюзії»

4. Бальзак і Україна.

\section{2. Питання для самоконтролю}

Середовище MOODLE надає широкі можливості для створення сторінки тестових завдань у діяльності «Урок»: множинний вибір, коротка відповідь, правильно / неправильно, есе тощо. Пропонуємо завдання відкритого типу із 
застосуванням типу питань «Есе», які дозволять викладачеві перевірити рівень засвоєння студентами теоретичного матеріалу:

Дайте короткі письмові відповіді на наступні запитання:

1. Розкрийте основний задум «Людської комедї»».

2. Які основні принципи побудови епопеї «Людська комедія»?

3. Які теми є провідними у творчості Бальзака?

4. Яку роль Україна відіграла у житті письменника?

\section{3. Навчальне відео}

У сучасному дистанційному навчанні велику роль відіграють відеоматеріали, оскільки відео є одним із найбільш ефективних засобів передачі інформації (Кухаренко, 2016). Зазвичай відео використовується у дистанційних курсах для підтримки та посилення теоретичного змісту, але воно може також представляти тьютора, презентувати предмет вивчення, роз'яснювати завдання, підсумовувати окремі теми або результати вивчення всього курсу. Статистика використання відео в MOOC (Massive Open Online Course) показує, що оптимальна тривалість одного навчального відеофрагменту не повинна перевищувати шести хвилин (Guo, 2013).

Мета навчального відео у нашому сценарії має подвійний характер: поперше, викладач розкриває задум та структуру «Людської комедії» Бальзака; подруге, він формулює індивідуальне завдання (для самостійного дистанційного виконання), яке має на меті підготувати студентів до аудиторної роботи.

Пропонуємо під час відео-лекції зробити акцент на наступних питаннях:

- Системність творчого методу Бальзака.

- Логіка побудови «Людської комедії».

- Наукові принципи та методи, застосовані Бальзаком у «Людській комедії».

- Формальні та змістовні чинники, які зв'язують усі твори в єдиний цикл.

Навчальне відео супроводжується презентацією, яку викладач додає до свого е-курсу (файл PDF).

\section{4. Індивідуальне завдання № 1 «Філософсько-естетичний зміст передмови до «Людської комедії»»}

Студентам пропонується прочитати передмову до «Людської комедії» Бальзака та дати відповідь на наступні питання:

1. Що ставить Бальзак на меті, створюючи «Людську комедію»?

2. Учому письменник вбачає власне новаторство?

Професіоналізм педагога: теоретичні й методичні аспекти. - Вип. 14 (Ч. 2). - Слов’янськ, 2021. 
3. Чому, на думку автора, прачя письменника подібна праиі науковия?

4. Які естетичні принципи формулює Бальзак у передмові?.

Запропоноване завдання націлене на більш глибоке розуміння творчого задуму Бальзака та підготовку до аудиторного практичного заняття.

\section{5. Тест за змістом роману Бальзака «Батько Горіо»}

Мета тесту - перевірити знання студентів змісту роману «Батько Горіо».

Орієнтовні тестові питання (множинний вибір із однією правильною відповіддю):

1. Батьки Ежена Растіньяка мали:

а) двох синів та одну дочку;

б) двох синів та двох дочок;

в) трьох синів та двох дочок;

г) трьох синів та трьох дочок

2. Який титул мала мадам де Босеан?

а) віконтеса;

б) графиня;

в) маркіза;

г) баронеса.

3. Який титул мала мадам де Ресто?

а) віконтеса;

б) графиня;

в) маркіза;

г) баронеса.

4. Який титул мала мадам де Нусінген?
а) віконтеса;
б) графиня;
в) маркіза;
г) баронеса.

5. Про що мріяв Вотрен?

а) вигідно одружитися;

б) придбати плантацію в Америці;

в) стати банкіром; 
г) пограбувати ювеліра.

6. Растіньяк знайомиться з Дельфіною де Нусінген:

а) на балу;

б) на Єлисейських Полях;

в) вдома у батька Горіо;

г) у театрі.

7. Де Растіньяк взяв гроші для того, щоб не соромно було з'являтися у вищому світі?

а) виграв у рулетку;

б) позичив у Вотрена;

в) продав сімейну реліквію;

г) попросив у матері.

8. Растіньяк у Парижі вивчає:

а) медицину;

б) право;

в) військову справу;

г) економічні науки.

9. Дельфіна де Нусінген передає Растіньяку через свого батька дарунок:

а) булавку для краватки;

б) модні рукавички;

в) годинник;

г) пасмо власного волосся.

10. Яким чином Растіньяк добув велику суму грошей для мадам де Нусінген?
а) виграв у рулетку;
б) позичив у Вотрена;
в) продав сімейну реліквію;
г) попросив у матері.

11. На початку роману батько Горіо сплачує борг своєї дочки завдяки продажу:
а) срібної чашки; 

б) золотої обручки;
в) порцелянової статуетки;
г) старовинної картини.

12. Рід діяльності чоловіка Дельфіни де Нусінген:

а) не працює, живе на ренту зі свого капіталу;

б) банкір;

в) власник ювелірного підприємства;

г) не працює, живе на ренту зі своїх земель.

13. Мільйонер Тайфер має:

а) двох синів та одну дочку;

б) одного сина та двох дочок;

в) одного сина та одну дочку;

г) двох дочок.

14. У Вотрена тавро каторжника містилося:
а) на руці;
б) на спині;
в) на нозі;
г) на плечі.

15. Растіньяк знайомиться з Анастазі де Ресто:
a) на балу;
б) на Слисейських Полях;
в) вдома у батька Горіо;
г) у театрі.

16. Що Растіньяк пропонує продати Дельфіні де Нусінген, аби можна було пристойно поховати ії батька?
а) годинник;
б) прикрасу;
в) скриньку;
г) порцелянову вазу.

17. Б'яншон вивчає у Парижі:

\section{a) медицину;}



б) право;
в) військову справу;
г) економічні науки.

18. На знак своєї приязні мадам де Босеан дарує Растіньякові:
а) годинник;
б) прикрасу;
в) скриньку;
г) порцелянову вазу.

19. Яким чином діє Вотрен під час арешту?
а) намагається втекти;
б) стріляє в поліцейських;
в) вчиняє самогубство;
г) здасться без опору.

20. Для сплати боргів свого коханця Анастазі де Ресто продає:
а) діаманти;
б) фамільне золото;
в) унікальну обручку;
г) коштовну картину.

\section{6. Практичне заняття «Роман О. Бальзака «Батько Горіо» як «роман кар'сри»"»}

Практичне заняття проводиться в аудиторії, е режимі offline. Викладач проводить розгорнуту бесіду з елементами дискусії за наступним орієнтовним планом:

1. Зображення середовища в романі «Батько Горіо»: описи Парижа, пансіону пані Воке тощо.

2. Образна система роману:
а) Ежен де Растиньяк - виклик Парижу;
б) образи Вотрена, баронеси де Босеан, матері героя - моральні аспекти твору;
в) образ батька Горіо та його місце в романі - шекспірівська тема. 
3. Сюжетно-композиційна будова роману (роль експозиції, основні етапи розгортання конфлікту, сенс фіналу, прийом контрасту). Позасюжетні елементи: міський пейзаж та інтер'єр, їхня роль в розкритті основних проблем.

4. Два романи кар'єри: порівняльна характеристика романів «Червоне $\mathrm{i}$ чорне» та «Батько Горіо» (жанрові особливості, образ головного героя).

Практичне заняття має на меті реалізацію таких елементів засвоєння, як застосування та аналіз. Студенти мають можливість використати опанований теоретичний матеріал у процесі аналізу художнього твору.

\section{7. Індивідуальне завдання № 2 «Особливості творчого методу О. де Бальзака»}

Друге індивідуальне завдання складається з двох етапів роботи, кожний із яких оцінюється до 10 балів. На першому етапі студенти повинні самостійно встановити основні особливості творчого методу Бальзака. Запропоноване завдання націлене, за таксономією Б. Блума, на синтез і потребує від студентів здатності до творчого поєднання одержаних знань та навичок під час вивчення всієї теми.

На другому етапі студенти мають дати обгрунтовану оцінку кільком визначенням особливостей творчого методу Бальзака, які були встановлені іншими студентами цієї ж групи (за таксономією Б. Блума - рівень оцінювання). Студентам пропонується дати відповіді на питання:

- Які з представлених особливостей творчого методу Бальзака обумовлені ідейно-естетичною спеиифікою реалізму XIX століття $i$, 6 цілому, збігаються з особливостями творчого методу інших письменників-реалістів ијєї доби?

- Які з представлених особливостей творчого методу Бальзака відрізняють його літературний доробок від інших письменниківреалістів ХІХ століття?

- Які з представлених особливостей, на Ваму думку, є зайвими / помилковими?

- Дайте оцінку пропонованій роботі за шкалою від 1 до 10.

- Зважаючи на зміст пропонованої роботи, чи внесли б Ви корективи до власного бачення проблеми?

- Дайте оиінку власній роботі за шкалою від 1 до 10.

Для виконання цього завдання найбільш придатним видом діяльності у середовищі MOODLE $€$ «Семінар». Цей модуль має технічну можливість збору та аналізу робіт із виставленням колегіальної оцінки. На семінарі студенти 
отримують дві оцінки: оцінку за свій матеріал та за оцінювання матеріалів своїх однокурсників.

\section{8. Підсумковий вебінар}

Наприкінці навчального тижня викладач проводить вебінар, під час якого аналізує всі видів діяльності студентів, зокрема приділяє особливу увагу індивідуальному завданню № 2, підводить підсумки навчального тижня, відповідає на поставлені запитання.

Платформа MOODLE дозволяє проводити вебінари безпосередньо у власному середовищі завдяки модулю BigBlueButton, який надає широкі можливості для навчальної діяльності: чат, мікрофон, веб-камера, голосування, демонстрація робочого столу або презентації, окремої вкладинки браузера або вікна будь-якої програми. Звичайно, викладач може скористатися й іншими безкоштовними або умовно безкоштовними вебінарними платформами: Google Meet, Zoom, Skype тощо.

\section{9. Щотижневе опитування}

Зворотний зв'язок зі студентами - важлива складова дистанційного навчання. У своїх е-курсах ми запровадили щотижневе опитування студентів, яке не тільки забезпечує «feedback», а й спонукає здобувачів вищої освіти до рефлексії. Найбільш придатним для цього у MOODLE v3 є вид діяльності «Анкета», а у MOODLE v2 можна використати тест типу «Есе».

Орієнтовні питання:

1. Опишіть Вашу мету на поточному тижні.

2. Що Ви зробили на поточному тижні?

3. Що Вам сподобалося (не сподобалося) в теоретичному матеріалі? Чому?

4. Що Вам сподобалося (не сподобалося) у практичних завданнях? Чому?

5. Які питання у Вас виникли протягом тижня?

6. Надайте рекомендації щодо покращення матеріалу.

7. Скільки часу Ви витратили на поточному тижні?

Висновки. Як бачимо, змішане навчання вимагає створення навчальнометодичного забезпечення, що відповідає сучасним стандартам якості надання освітніх послуг - доступності, інтерактивності, мультимедійності. Використання таких технологій дозволяє застосувати широкий спектр форм та засобів навчання, сприяє персоналізації навчального процесу, дає можливість реалізувати весь комплекс елементів засвоєння матеріалу (від знання до 
оцінювання), активізує пошукову діяльність не лише студентів, а й викладачів. Запропонований нами сценарій дозволяє реалізувати його в інформаційній системі навчального призначення MOODLE.

Перспективи подальшого науково-методичного пошуку вбачаємо, поперше, у проведенні педагогічних експериментів із метою виявлення найбільш ефективних моделей змішаного навчання i, по-друге, у створенні нових подібних сценаріїв.

\title{
СПИСОК ВИКОРИСТАНИХ ДЖЕРЕЛ
}

1. Бугайчук, К.Л. (2016). Змішане навчання: теоретичний аналіз та стратегія впровадження в освітній процес вищих навчальних закладів. Інформаційні технології $і$ засоби навчання, $54 \quad$ (4), 1-18. URL: http://www.irbis-nbuv.gov.ua/cgibin/irbis_nbuv/cgiirbis_64.exe?I21DBN=LINK\&P21DBN=UJRN\&Z21ID=\&S21REF=10\&S21CN $\mathrm{R}=20 \& \mathrm{~S} 21 \mathrm{STN}=1 \& \mathrm{~S} 21 \mathrm{FMT}=\mathrm{ASP} \_$meta\&C21COM=S\&2_S21P03=FILA=\&2_S21STR=ITZN_2 016_54_4_3

2. Кудін, А.П., Міненко, О.М. (2018). Сценарії технології змішаного навчання математики в системі MOODLE. Фізико-математична освіта. 1(15), 68-72.

3. Кузьменко, О. (2017). Змішане навчання як інноваційна форма організації навчального процесу в школі. Наукові записки Тернопільського національного педагогічного університету імені Володимира Гнатюка. Педагогіка, 3, 140-147.

4. Лист МOH України. № 1/9-344. (2020, 24 червня). URL: http://puet.edu.ua/sites/default/files/lyst_mon_ukrayiny_no1_9-344_vid_24.06.2020_r.pdf

5. Рашевська, Н.В. (2010). Змішане навчання як психолого-педагогічна проблема. Вісник Черкаського університету. Педагогічні науки, 191, 89-96.

6. Кухаренко, В.М. (2016). Теорія та практика змішаного навчання. Харків, Україна: Міськдрук.

7. Чепурних, Г.К. (2019). Використання моделі «змішаного навчання» під час викладання іноземної мови у немовному вузі. Молодий вчений, 5.1 (69.1), 223-227.

8. Шуневич, Б.І. (2009). Тенденція розвитку складових частин організації дистанційного навчання. Вісник Національного університету «Львівська політехніка», 653, 231-239.

9. Bonk, C.J., Graham, C.R. (2006). The handbook of blended learning environments: Global perspectives, local designs. URL: http://curtbonk.com/toc_section_intros2.pdf

10. Guo, Ph. (2013). Optimal Video Length for Student Engagement. URL: https://blog.edx.org/optimal-video-length-student-engagement

\section{SCENARIO OF BLENDED LEARNING OF FOREIGN LITERATURE IN THE PROCESS OF STUDYING THE TOPIC «THE WRITING OF HONORÉ DE BALZAC»}

\author{
Igor Kazakov \\ Candidate of Philological Sciences,
}

Head of the Russian Language and Literature Department

SHEI “Donbas State Pedagogical University", Sloviansk, Donetsk region, Ukraine

ORCID ID 0000-0002-7536-6723

kazakov.i@i.ua 


\title{
Viktor Razzhyvin \\ Candidate of Philological Sciences, Associate Professor Ukrainian Language and Literature Department \\ SHEI “Donbas State Pedagogical University”, Sloviansk, Donetsk region, Ukraine ORCID ID 0000-0002-4512-8791 \\ vrazzhivin@i.ua
}

\begin{abstract}
The article proposes a blended learning scenario in the study of the topic "The Creativity of Honore de Balzac" in the course of World Literature for higher educational institutions. The 2020-2021 pandemic has led to the relevance of using blended learning in domestic higher education. The spread of COVID-19 and the spread of coronavirus disease in Ukraine has accelerated the transition of universities and lecturers to interactive forms of education. Blended learning is a hybrid methodology based on the creative combination of online learning and traditional (classroom) learning. This type of training has many benefits.

Analysis of recent research and publications shows a fairly high level of acquirement of the theory of blended learning in the domestic space. There are many publications devoted to the generalization of scholar works of Western scientists and the justification of the need for the introduction of blended learning in Ukraine. The practical component, based on the development of specific models and scenarios, is less represented, which determines the relevance of this study.

The aim of the article is to develop a scenario of blended learning of World Literature on the example of studying the topic "Creativity of Honore de Balzac". The proposed scenario was integrated into the MOODLE platform environment. It uses the popular rotating model «inverted class»». As Balzac's works occupy a prominent place in the literary process of the XIX century, we propose to dedicate a separate academical week to the study of this topic, the plan of which the lecturer places on his e-course.Plan and description of the training activities for this scenario are presented later.

In summary, blended learning requires the creation of educational and methodological support that meets modern quality standards for the provision of educational services - accessibility, interactivity, multimediality. Blended learning technologies make it possible to apply a wide range of forms and teaching aids that contribute to the personalization of the educational process, make it possible to implement the entire range of elements of mastering the material (from knowledge to assessment), and activate the search activity of not only students, but also lecturers.
\end{abstract}

Key words: blended learning; modern teaching methods; distance technologies; teaching methodology; World Literature; Honore de Balzac.

\section{REFERENCES}

1. Buhaichuk, K.L. (2016). Blended learning: theoretical analysis and strategy of introduction of higher educational institutions into the educational process. Information technologies and teaching aids, 54 (4), 1-18. URL: http://www.irbis-nbuv.gov.ua/cgibin/irbis_nbuv/cgiirbis_64.exe?I21DBN=LINK\&P21DBN=UJRN\&Z21ID =\&S21REF=10\&S21CN $\mathrm{R}=20 \& S 21 \mathrm{STN}=1 \& \mathrm{~S} 21 \mathrm{FMT}=\mathrm{ASP} \_m e t a \& C 21 \mathrm{COM}=\mathrm{S} \& 2 \_S 21 \mathrm{P} 03=\mathrm{FILA}=\& 2 \_S 21 \mathrm{STR}=\mathrm{ITZN} \_2$ 016_54_4_3

2. Kudin, A.P., Minenko, O.M. (2018). Scenarios of blended learning mathematics technology in the MOODLE system. Physical and mathematical education, 1(15), 68-72.

3. Kuzmenko, O. (2017). Blended learning as an innovative form of organization of the educational process in school. Scientific notes of Ternopil National Pedagogical University named after Volodymyr Hnatyuk. Pedagogy, 3, 140-147.

Професіоналізм педагога: теоретичні й методичні аспекти. - Вип. 14 (Ч. 2). - Слов’янськ, 2021. 
4. Letter from the Ministry of Education and Science of Ukraine № 1/9-344. (2020, June 24). URL: http://puet.edu.ua/sites/default/files/lyst_mon_ukrayiny_no1_9-

344_vid_24.06.2020_r.pdf

5. Rashevska, N.V. (2010). Blended learning as a psychological and pedagogical problem. Bulletin of Cherkasy University. Pedagogical Sciences, 191, 89-96.

6. Kukharenko, V.M. (2016). Theory and practice of blended learning. Kharkiv, Ukraine: City Press.

7. Chepurnykh, H.K. (2019). Using the model of «blended learning» when teaching a foreign language in a non-language university. Young Scientist, 5.1 (69.1), 223-227.

8. Shunevych, B.I. (2009). The trend of development of the components of the organization of distance learning. Bulletin of the National University "Lviv Polytechnic", 653, 231-239.

9. Bonk, C.J., Graham, C.R. (2006). The handbook of blended learning environments: Global perspectives, local designs. URL: http://curtbonk.com/toc_section_intros2.pdf

10. Guo, Ph. (2013). Optimal Video Length for Student Engagement. URL: https://blog.edx.org/optimal-video-length-student-engagement 